\title{
Dualistiese antropologie by Paulus?
}

\author{
G M M Pelser \\ Departement Nuwe-Testamentiese Wetenskap \\ Universiteit van Pretoria
}

\begin{abstract}
Dualistic anthropology in Paul?

The question as to whether Paul's anthropology can be qualified as dualistic is, with a few exceptions, usually answered in the negative. However, although the vast majority of scholars favour the negative answer, it cannot be denied that there are instances in the Pauline correspondence which are suspect, to say the least. It is for this reason that the debate has not come to a rest yet, and that the issue is still raised from time to time. The present study was prompted by recent contributions to the debate, especially those of Boyarin (1994) and Crossan (1998), in which it is claimed that Paul's anthropology can indeed be qualified as dualistic. The outcome of the study is that one has every reason to believe that in a number of passages Paul not only made use of dualistic terminology and concepts, but that he actually also conceived of human existence in a dualistic manner.
\end{abstract}

\section{AANLEIDING}

As aanleiding vir hierdie ondersoek het gedien die standpunt wat Crossan (1998), veral in reaksie op die uitsprake van Boyarin (1994), in verband met Paulus se antropologie gestel het. Soos elkeen wat reeds met die genoemde werk van Crossan kennis gemaak het weet, het hy hiermee veral gereageer op Boyarin se oortuiging dat Paulus 'n kompromie probeer bewerkstellig het tussen die antropologiese denke van onderskeidelik die Hellenistiese en die Joodse wêrelde, wat albei deel gevorm het van sy agtergrond en van die adres van sy evangelie. Volgens Boyarin het Paulus hom bevind tussen die dualisme van die gnostici aan die een en die monisme van die Jerusalemse gemeente aan die ander kant. Hy het hierdie twee met mekaar probeer versoen deur enersyds soos Philo 'n konsekwent dualistiese antropologie van gees teenoor liggaam te handhaaf (kyk Boyarin 1994:59), maar andersyds soos by die gematigde Platonisme nie negatief oor die liggaam te dink as ' $n$ kerker of nie-essensiële omhulsel waaruit ' $n$ mens verlos moet word nie (kyk 
Boyarin 1994:60). Dit beteken volgens Boyarin egter nie dat Paulus die liggaam as gelykwaardig aan die mens se innerlike geag het nie. Inteendeel, "the image of the human being which Paul maintains is of a soul dwelling in or clothed by a body, and, however valuable the garment, it is less essential than that which it clothes" (kyk Boyarin 1994:60; kyk ook 185). Die kompromie was dus dat Paulus hom volledig met die $\pi \nu \varepsilon \hat{u} \mu \alpha-\sigma \hat{\omega} \mu \alpha / \sigma \alpha ́ \rho \xi$ dualisme vereenselwig het, maar aan die liggaam 'n ondergeskikte plek teenoor die gees toegeken het.

Hoewel Crossan nie van Boyárin oor die kwessie van dualisme by Paulus of oor die gedagte van 'n kompromie verskil nie, wys hy daarop dat Boyarin nie raakgesien het dat Paulus hierdie kompromie op inkonsekwente wyse deurgevoer het nie. Crossan oordeel naamlik, met spesifieke verwysing na Galasiërs 3:28, dat Paulus nie ten opsigte van klas- en geslagverskil dieselfde graad van negering van toepassing gemaak het as wat hy in die geval van etnisiteit gedoen het nie. Hy het wel die etnisiteitnegasie na buite, na die strate van die Romeinse stede geneem, maar nie dieselfde gedoen met klas- en geslagnegasie nie. Met ander woorde hy het nie in verband met etnisiteit soos in die geval van klas en geslag gesê dat die verskille religieus en spiritueel irrelevant voor God is, maar dat dit fisiek en sosiaal gehandhaaf moet word nie. "The contradiction is not that he took all three spiritually but that he took one physically as well as spiritually" (Crossan 1998:XXV). Dit beteken dat terwyl hy sy lesers laat verstaan het dat daar in Christus geen hiërargiese verskil meer tussen volke getref kan word nie, hy nie dieselfde met klas en geslag gedoen het nie. Crossan se standpunt berus natuurlik op die oortuiging dat Paulus hom nie werklik ten gunste van die emansipasie van die vrou (1 Kor 11:3-11) of die vrylating van slawe (1 Kor 7:21; Filem) uitgespreek het nie, iets wat Paulus, soos bekend, al dikwels kwalik geneem is met die verwyt dat hy in hierdie opsig 'n konserwatiewe etiek daarop nagehou het (kyk bv Keck 1979:94-98).

Dit is naturlik nie heeltemal korrek om te sê dat Boyarin nie iets van ' $n$ inkonsekwensie raakgesien het nie; hy het dit net nie so sterk uitgelig as Crossan nie. Volgens hom was Paulus inderdaad van oortuiging dat die doop 'n nuwe skepping teweeg sou bring, maar dat dit nie nou reeds op sosiale vlak 'n werklikheid sou word nie (Boyarin 1994:187). Hy oordeel verder dat hoewel dit vir Paulus moontlik was om hom die wegneem van die verskil (nl die besnydenis) tussen Jood en nie-Jood in te dink, hy hom net 
so min as enigiemand anders van sy tyd kon voorstel dat "male and female bodies would be in any condition other than dominant and dominated when they were in sexual relationship with each other" (Boyarin 1994:190). Paulus was nie inkonsekwent omdat dit sy bedoeling was om manlike privilegie te handhaaf nie, maar omdat hy van oortuiging was dat die bevryding van vroue die einde van die huwelik sou beteken (Boyarin 1994:199-200). Vir Boyarin is daar ook nie 'n teenspraak tussen Galasiërs en 1 Korintiërs wat betref die kwessie van geslagtelikheid nie. Die rede waarom Paulus hom wel in hierdie twee dokumente verskillend oor die status van man en vrou uitgelaat het, is omdat die Galasiërs te veel klem op die liggaamlike gelê het en die Korintiërs te veel op die pneumatiese. "There is thus no contradiction on Paul's thought at all. He held out the possibility of a momentary ecstatic androgyny but only that; on the corporeal level of human society, sex/gender difference was maintained" (Boyarin 1994:190).

Behalwe bogenoemde inkonsekwensie is daar na Crossan se oordeel ook nog 'n verdere antropologiese inkonsekwensie by Paulus waar te neem, naamlik in die wyse waarop hy die opstanding in 1 Korintiërs 15 verduidelik. Crossan oordeel dat om die opstanding te verduidelik deur te wys op die verskil tussen aardse en hemelse liggame (verse 39-40), nie dieselfde is as om dit te doen aan die hand van die metafoor van die saadkorrel en die plant nie (verse 36-38). As 'n mens ten opsigte van eersgenoemde sou vra of daar ' $n$ fisiese en materiële kontinuïteit tussen die aardse en die opgestane liggaam is, sal die antwoord "nee" wees: die aardse liggaam is 'n fisiese liggaam, die opgestane liggaam is ' $n$ geestelike liggaam. As 'n mens dieselfde vraag ten opsigte van laasgenoemde sou vra, sal die antwoord egter "ja" wees, want dit impliseer dat die opgestane liggaam tegelyk "totally the same and absolutely different" sal wees (Crossan 1998: XXIX). "The seed that is sown and the grain that is produced are both same and different and are in unbroken material and physical continuity" (Crossan 1998:XXX). Wat is dan nou, volgens Crossan, die inkonsekwentheid waaraan Paulus hom hier skuldig gemaak het? Dit is dat hy te midde van 'n Hellenisties-Joodse verduideliking vir 'n oomblik van 'n Joods-Joodse argumentasie gebruik gemaak het. Dit wil sê sy Joodse monisme het vir 'n oomblik harder gepraat as sy genoemde dualistiese kompromie.

Moet Crossan gelyk gegee word? Om op hierdie vraag te probeer antwoord, sal nie moontlik wees as ' $n$ mens nie eers vir jouself uitgemaak het of daar inderdaad van 


\section{Dualistiese antropologie by Paulus?}

dualisme in Paulus se antropologie sprake is en wat die aard daarvan is nie. Die geskiedenis van die navorsing toon dat dit nie 'n maklike onderneming is nie en dat daar aansienlike meningsverskil, natuurlik met variasies, oor die saak bestaan. In hoofsaak verdeel die opinies egter maar in pro en anti standpunte.

\section{WAT IS EN VANWAAR KOM DUALISTIESE ANTROPO- LOGIE?}

Die bedoeling is nie om hier uitvoerig in te gaan op wat onder dualistiese antropologie te verstaan is nie, maar slegs om op die hooftrekke daarvan te wys soos ' $n$ mens dit in die literatuur teëkom. Wat in sodanige literatuur eerste opval, is dat onderskei word tussen dualiteit en dualisme. Onder dualiteit word dan min of meer verstaan die oortuiging dat die mens saamgestel is uit minstens twee dele of substansies, 'n innerlike en 'n uiterlike,

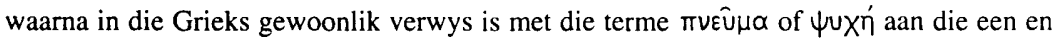
$\sigma \omega \hat{\mu \alpha}$ of $\sigma \alpha \dot{\rho} \xi \xi$ aan die ander kant. Verder is die uiterlike of materiële deel hier nie in 'n negatiewe lig gesien nie, hoewel dit nie altyd as gelykwaardig aan die innerlike beskou is nie. Hierteenoor word onder dualisme verstaan die beskouing dat menslike eksistensie nie alleen gekenmerk word deur die anwesigheid van 'n innerlike en uiterlike substansie nie, maar ook dat laasgenoemde intrinsiek van negatiewe aard of boos is, sodat eersgenoemde daarvan bevry moet word. Tradisioneel is ook aanvaar dat dualisme soos hier gedefinieer nie kenmerkend was van Joodse nie, maar wel van Hellenistiese antropologie en dat dit teruggaan op Plato se ideëleer. So het Davies byvoorbeeld nog met stelligheid beweer: "In Hellenistic thought it is not the purification of the flesh that is desired but escape from it, because the 'flesh' is conceived there not only as the sphere where evil dwells but as itself constituting evil" (Davies 1990:162; my beklemtoning).

Nie almal is egter daarvan oortuig dat 'n dualistiese mensbeskouing inderdaad op Plato teruggevoer kan word nie, afgesien nog van die gedagte van die innerlike mens as intrinsiek goed en onsterflik en die uiterlike as intrinsiek boos en verganklik. In 'n betreklik onlangse ondersoek na die konsep "innerlike mens" by Plato het Markschies daaraan herinner dat die innerlike mens by Plato maar net een van drie sieldele van die

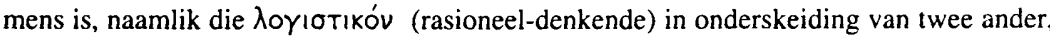

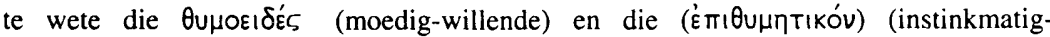


begerende) dele (Markschies 1994:2; kyk ook Heckel 1993:19). Hy wys verder daarop

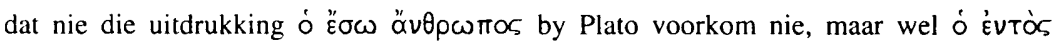

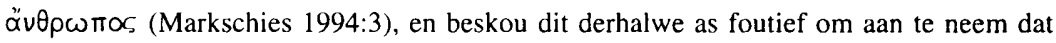
die uitdrukking by Plato en daarna 'n eenduidige tegniese term was. Dit word byvoorbeeld ook nie gebruik deur Plato se leerling, Aristoteles, die ouere Stoa, die keiserlike Stoa, die middel-Platonici, Plutarchos, Philo of die Corpus Hermeticum nie, en word eers 'n tegniese term by die Neo-Platonici en die Kerkvaders (Markschies 1994:6-7; vgl Heckel 1993:26-30). Markschies oordeel ook dat die begrip by Paulus nie volledig ooreenstem met dié van Plato nie, dat dit nie alle betekenisse van die Plato-begrip dek nie en dat Platoniste hulle veral moeilik met die gedagte van daaglikse vernuwing ( 2 Kor 4:16) sou kon vereenselwig (Markschies 1994:3).

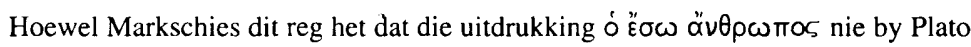
en die ander genoemde filosowe en outeurs voorkom nie, maar eers in die na-NuweTestamentiese era ' $n$ tegniese term geword het, hoef dit nie te beteken dat dit ook geld van die begrip "innerlike mens" nie. 'n Mens sal kwalik kan oordeel dat Plato met

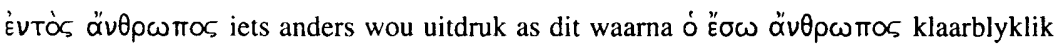
bedoel was om te verwys. Dit word onder andere bevestig deur die feit dat Plato die

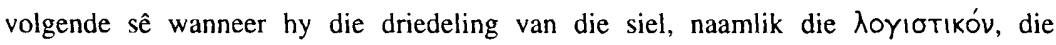

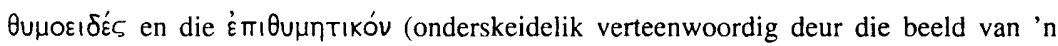

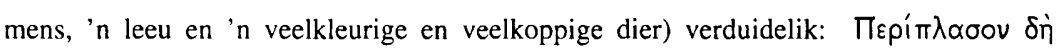

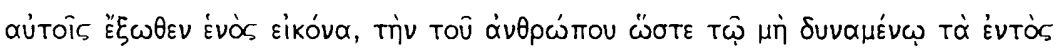

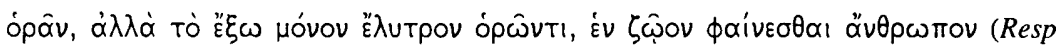
9:588E). Hiermee stel hy uitdruklik dat wanneer hierdie drie deur die een beeld, naamlik

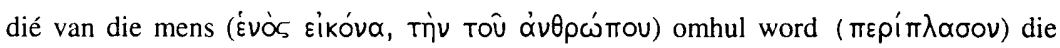

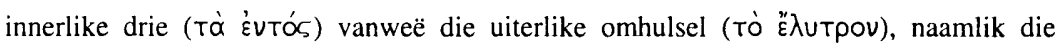
liggaam, nie sigbaar is nie, sodat dit voorkom of jy, van buite gesien, met net één lewende wese, één mens, te doen het. Hier word duidelik tussen 'n innerlike en uiterlike

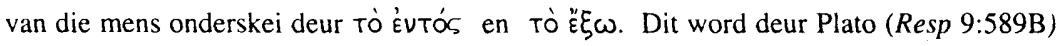
verder onderstreep deurdat hy in dieselfde konteks as die hierbo genoemde uitspraak sê dat om jou met die regte dinge besig te hou en die regte dinge te sê, die innerlike mens

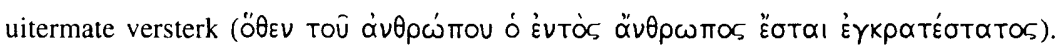


Wat in 'n sekere sin Markschies se argument ondersteun, is dit waarop Aune attent gemaak het, naamlik dat Plato se beskouings oor die onderhawige saak gedurende sy leeftyd radikaal verander het en nooit in 'n koherente sisteem inforseer is nie. Die opvallendste volgens Aune was die verandering van die beskouing van $\psi u \times \eta$ as 'n enkele substansie in Phaedo na die drieledige verdeling daarvan in die Respublica, terwyl dit selfs ook in Phaedo met 'n relatief wye spektrum van konnotasies gebruik word (Aune 1995:292). Aan die ander kant wys Markschies self daarop dat iemand soos Philo van

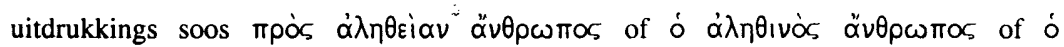

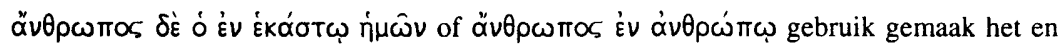

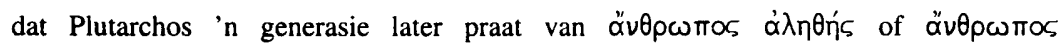
mVEUHaTıKós (Markschies 1994:7). Hoewel 'n mens moet toegee dat ons hier nog nie met een eenduidige tegniese term te make het nie, lyk dit voor die hand liggend dat daar in hierdie uitdrukkings, afgesien nog van die konteks waarin dit voorkom, tog "begripmatig" die gedagte van 'n innerlike mens opgesluit lê. Al sou die saak by Plato dan ook betreklik onseker blyk te wees, kan dieselfde kwalik van Philo gesê word. Volgens Heckel (1993:52) se berekening kom die "innerlike mens" motief in die werke van Philo "in mehr oder weniger Ausprägung über ein dutzendmal" voor.

Al sou ' $n$ mens moet saamstem dat daar nie so iets as ' $n$ eenduidige dualisme geidentifiseer kan word nie, neem dit nie weg dat daar tog bepaalde beskouings bestaan het wat vir ons vraag van belang is nie. Aune (1995:294-295) het in 'n vergelyking wat hy tussen die prominentste Hellenisties-filosofiese tradisies getref het, tot die slotsom gekom dat daar ten spyte van die verskille die volgende gemeenskaplikhede aan te merk is:

a) Almal het die siel van die liggaam onderskei.

b) Almal het die siel as die sentrum van intellek beskou.

c) Almal het die siel gesien as gehuisves in 'n bepaalde deel van die liggaam.

d) Almal het verstandelike en morele kwaliteite aan die siel toegeken, maar nie aan die liggaam nie.

e) Almal het geglo die siel het beide rasionele en irrasionele aspekte.

f) Almal, behalwe die Epikuriërs en die Stoïsyn, Panaetus, het geglo dat die siel minstens vir 'n sekere tyd ná die dood bly voortleef. 
In bogenoemde vergelyking is daar duidelik niks daarvan te bespeur dat materie as intrinsiek boos en gees as intrinsiek goed beskou is nie. Dit is volgens Aune eers gedurende die tweede eeu $\mathrm{nC}$ en later dat Platoniese idealisme so geïnterpreteer is. Hy wys verder daarop dat die gedagte dat die liggaam intrinsiek boos is en as 'n tydelike gevangenis van die onsterflike siel dien, primêr geassosieer word met Plato se Phaedo, maar dat Plato in sy Timaeus die gedagte uitspreek dat beide die siel en die liggaam geoefen moet word sodat hulle gelykwaardig en albei gesond sal wees (Aune 1995:296). Dit blyk dat ook Aristoteles die siel-liggaam dualisme positief waardeer het, terwyl die materiële monisme van die Epikuriërs en die vroeë Stö̈syne inhou dat ook húlle 'n positiewe gesindheid jeens fisieke eksistensie openbaar het (Aune 1995:297).

Hoewel daar niks van die intrinsieke boosheid van die liggaam in bogenoemde samevatting van die belangrikste trekke van die Hellenistiese antropologiese tradisies te bespeur is nie, is dit nietemin duidelik dat die liggaam in 'n aansienlike mate minderwaardiger en vergankliker as die siel geag is. Dit bring ons by die vraag of Paulus ook so oor die saak gedink het.

\section{DUALISME BY PAULUS?}

Wat opmerklik is wanneer 'n mens kyk na die resultate van die ondersoeke wat reeds in verband met hierdie saak gedoen is, is dat die antwoord in die meeste gevalle negatief is. Dit blyk ook dat wanneer daar wel geoordeel word dat Paulus hom by 'n geleentheid of twee van dualistiese terminologie bedien het, dit in die meeste gevalle só verklaar word dat hy nie werklik van dualisme beskuldig kan word nie. Om mee te begin, kan gewys word op die argument van Bultmann wat stel dat Paulus nie dualisties die "ek" van die mens (die "Seele") onderskei het van die liggaam(like) as 'n nie-gelykwaardige omhulsel of kerker nie en dat sy hoop nie gerig was op die bevryding van die "ek" uit die gevangenis van die liggaam nie, maar wel op die opstanding of verandering van die

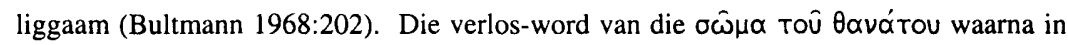

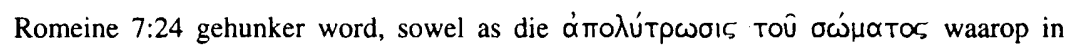
Romeine 8:23 gehoop word, verklaar Bultmann as duidend op die mens se bevryding van

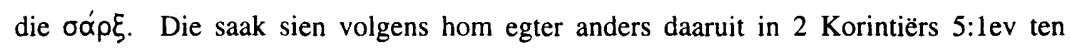
opsigte waarvan hy toegee dat Paulus hier "sehr nahe" aan die Hellenisties-Gnostiese 


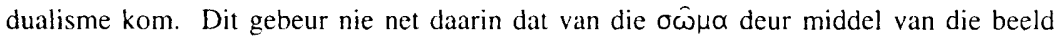
van 'n tentwoning en 'n kledingstuk gepraat word nie, maar ook in die gedagte van inwoon en uitwoon self. Die $\sigma \omega \hat{\mu \alpha}$ word hier geskets as die omhulsel van die ek, die

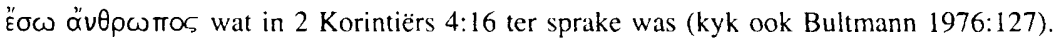

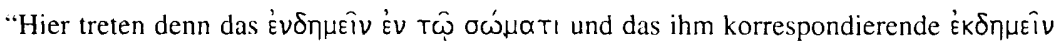

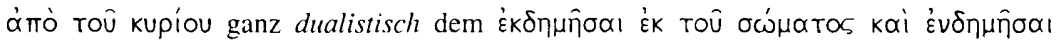
тра̀s Tòv kúpıov gegenüber" (Bultmann 1968:202; my beklemtoning). Min of meer dieselfde benadering vind ' $n$ mens by Conzelmann (1968:198-200) wat aan die een kant stellig daaroor is dat Paulus se antropologie nie dualisties is nie, maar ten opsigte van 2 Korintiërs 5:1vv toegee dat dit sterk dualisties gevorm is (Conzelmann 1968:200). 'n Variasie op die tema vind ' $n$ mens by Schnelle $(1991: 75,126)$ wat oordeel dat daar nie by Paulus van 'n metafisiese of antropologiese dualisme sprake is nie, maar eerder van 'n historiese (kyk ook Gundry 1976:83; Dunn 1998:477; vgl Barnett 1997:250, n 7). Dit gaan vir hom daarom dat wanneer Paulus uitsprake maak wat oënskynlik aan Hellenistiese dualisme ontleen is, hy in werklikheid oor die mens vanuit verskillende gesigspunte praat, dit wil sê vanuit die gesigspunt van die mens wat enersyds in selfgesentreerdheid volhard en andersyds hom/haar deur die krag van die Gees in die diens van God laat stel. Voeg hierby die opinie van Gundry dat ons by Paulus te make het met die erkenning van die dualiteit van menswees wat ' $n$ weerspieëling is van die Joodse teologie van sy tyd en dus nie verteenwoordigend is van ' $n$ metafisiese dualisme waarvolgens die liggaam boos is nie (Gundry 1976:83). Al wat hierdie dualiteit sê, is dat die mens uit twee substansies, die liggaamlike en die nie-liggaamlike, bestaan wat die moontlikheid het om van mekaar geskei te raak. Die verskil en skeidingsvermoë van die twee substansies impliseer nie dat die liggaamlike minderwaardig is nie (Gundry 1976:83-84; kyk ook Bottomley 1979:30).

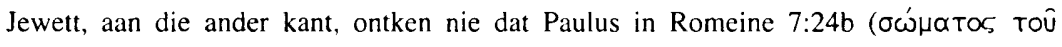

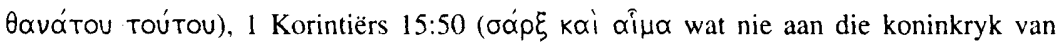

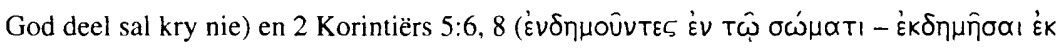
Toû $\sigma \omega ́ \mu \alpha T O 5)$ Gnostiese gedagtes gebruik of baie na daaraan kom nie. Hy meen egter dat dit 'n afwyking van Paulus se gebruiklike antropologie is en verklaar dit soos ander voor hom (Bultmann 1967:299-300; Schmithals 1969:248-249; Hoffmann 1969:253; Martin 1986:91), ten minste in die geval van die Korintiërbriewe, teen die agtergrond van 
die Gnostiese opponente wat in Korinte bedrywig was (Jewett 1971:265-267, 275-276; kyk ook Heckel 1993:6-7, 108-124). So meen hy het Paulus byvoorbeeld in 2 Korintiërs 5:1-10 van Gnostiese denke gebruik gemaak om juis die teenoorgestelde as die gnostici te stel. Hy het naamlik die standpunt gestel dat die lewe na die dood 'n liggaamlike eksistensie sal wees en het daarmee die Gnostiese gedagte van die siel wat na die dood hemelwaarts gaan om 'n naakte eksistensie te voer, verwerp (Jewett 1971:275-276). Op grond van sy reeds genoemde oortuiging dat die voorstelling van die "innerlike mens" nie by Plato voorkom nie en ook nog nie as tegniese term in die Nuwe-Testamentiese tyd gegeld het nie, beskou Markschies hierdie verklaring van Jewett as onaanvaarbaar (so ook Perkins 1986:521). Volgens hom kon hierdie voorstelling derhalwe niks anders as 'n Pauliniese skepping gewees het nie. "Weil die Vorstellung vom 'inneren Menschen' terminologisch (und wohl auch begrifflich) nicht eindeutig festgelegt war, handelt es sich vielleicht gar nicht um eine in Korinth aufgschnappte Wendung, sondern um eine ad hoc vorgenommene paulinische Wortprägung" (Markschies 1994:4; so ook Aune 1995:302; vgl Perkins 1986:519).

Sonder om vir mense woorde in die mond te wil lê of simplisties te redeneer, kan 'n mens nie anders as om onder die indruk te kom van hoe daar, minstens in sekere van die bogenoemde gevalle, as ' $t$ ware daarvan weggeskram is om te erken dat Paulus ' $n$ dualistiese antropologie daarop nagehou het en hom sodoende met Hellenistiese denke vereenselwig het nie. Word die oorname van Hellenistiese gedagtes nie summier afgewys nie (Gundry 1976), word die aanwesigheid van die verdagte formulerings op so ' $n$ wyse verklaar dat Paulus bo alle verdenking bly (Jewett 1971). Of daar word toegegee dat hy wel in gevalle soos Romeine 7:14-25 gebruik gemaak het van die dualisme van ' $n$ goeie gees of siel in 'n bose of swak fisiese liggaam, maar dan word gestel dat dit een van die "rare uses" van hierdie gedagte by hom is (Sanders 1991:93).

Dit is op hierdie punt nodig om daarop te wys dat daar na meer as 'n eeu se debat nog steeds wye terreine van verskil bestaan oor die vraag of Paulus in sy antropologie net deur sy Joodse agtergrond beinvloed is of ook deur Hellenistiese opvattings (so tereg Aune 1995:291). Wat die saak verder problematiseer is die standpunt wat vandag oor ' $n$ wye front gehuldig word, naamlik dat 'n mens nie meer kan praat van die oorname van gedagtes van "Judaïsme", "Hellenisme" of "Hellinistiese Judaïsme" nie, aangesien daar 
eenvoudig nie sulke geïsoleerde, teenoor mekaar afgegrenste denkrigtings bestaan het nie (Aune 1995:291). Onder andere verteenwoordigend van hierdie standpunt is die volgende uitspraak van Davies: "The recognition has grown that the first-century milieu against which we are to place Paul was variegated and, above all, complex. In particular has it become clear that the traditional convenient dichotomy beween Judaism and Hellenism was largely false" (Davies 1990:157). Dit beteken dat die tradisionele uitgangspunt dat die antieke mensbeskouings óf monisties óf dualisties moes wees en dat eersgenoemde die tipies Joodse en laasgenoemde die tipies Hellenistiese was, ook nie meer gehandhaaf kan word nie. So was die antropologie van die Stoïsyne en die Epikuriërs byvoorbeeld monisties en was daar in die Judaïsme ook dualistiese opvattings aanwesig. Dit is verder ' $n$ vraag of ons van 'n Pauliniese "antropologie" kan praat. Aune is naamlik van oortuiging dat Paulus nie 'n konsekwente opvatting oor die menslike natuur probeer ontwikkel het nie, en dat hoewel hy van Griekse antropologiese terme gebruik gemaak het, hy dit ad hoc gedoen het, sodat net 'n geringe mate van konsekwentheid te bespeur is as die verskillende gebruiksgevalle met mekaar vergelyk word. "Paul has more to say about human nature than any other early Christian author, yet he never deals with the subject directly, nor do the fragmentary expressions of his views of human nature exhibit internal consistency" (Aune 1995:299). Hierby wys Aune daarop dat Hellenistiese mensbeskouings uiters gevarieerd en kompleks was en dat daar in die Nuwe-Testamentiese Wetenskap dikwels ' $n$ karikatuur daarvan gemaak is. Dit is op grond van hierdie waarnemings dat hy oordeel dat daar net so min van dié Pauliniese mensbeskouing gepraat kan word as van dié Platoniese, of Aristoteliese of Stoïsynse (Aune 1995:292).

Dit word gou duidelik dat van al die gevalle ten opsigte waarvan daar in ' $n$ mindere of meerdere mate vermoedens van dualisme by Paulus bestaan ( $\mathrm{nl}$ Rom 6:6; 7:24; $8: 10-13 ; 1$ Kor $5: 3-5 ; 9: 27 ; 15: 50 ; 2$ Kor 5:1-10;12:3) 2 Korintiërs 5:1-10 beskou word as die sterkste aanduiding daarvan, hoewel hierdie perikoop, soos bekend, in die geskiedenis van die eksegese gesorg het vir uiteenlopende interpretasies (kyk vir 'n oorsig by Wolff 1989:101-105). Eintlik is hierdie uiteenlopendheid te begrype in die lig van die feit dat ons hier sonder twyfel met een van die eksegetiese krukse van die Pauliniese literatuur te doen het, hoewel Schmithals van oortuiging is dat die perikoop 'n mens net 
voor probleme stel "wenn man ihn unvermittelt als Quelle zur Feststellung der paulinischen Anthropologie und Eschatologie benutzen will" (Schmithals 1969:247). Hiermee bedoel hy dat die perikoop alleen probleme gee wanneer daar nie daarmee rekening gehou word dat dit polemies gerig is teen die gnostici in die Korintiese gemeente nie. Of Schmithals dit reg het oor die oorsaak van hierdie eksegetiese uiteenlopendheid of nie, feit is dat daar in hierdie perikoop soveel is wat in die rigting van een of ander dualisme wys, dat dit moeilik sal wees om die teendeel bo alle twyfel te bewys. Dit blyk te meer die geval te wees as ' $n$ mens die perikoop lees teen die agtergrond van die uitspraak in 2

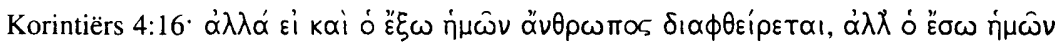

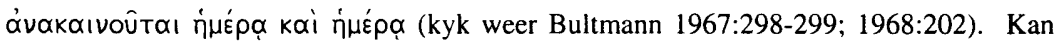
hierdie uitspraak anders verstaan word as dat Paulus hiermee die uiterlike mens of dan die uiterlike bestaansvorm van die mens as verganklik voorgestel het, teenoor die innerlike mens as die blywende, om nie te sê onsterflike, komponent van menswees? Reeds hier het ons dus te doen met 'n dualisme van die innerlik-blywende teenoor die uiterlik-verganklike van menswees (so tereg o a Windisch 1970:152; Wolff 1989:99; Walter 1996:56), behalwe natuurlik as 'n mens saam met Lietzmann (1969:117) sou

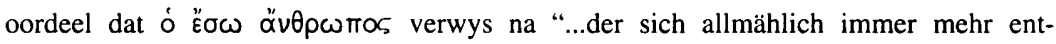
wickelnde Keim der 'neuen Kreatur', der werdende 'Christus im Christen'” (vgl ook Best 1987:45; Kremer 1990:49-50). Min of meer verwant aan hierdie interpretasie is die oordeel van Barnett (1997:250 n 7) dat ons hier nie met 'n psigologiese dualisme te make het nie maar met 'n eskatologiese, naamlik die realiteit dat die gelowige gelyktydig in beide die huidige en die toekomstige bedeling leef, onderskeidelik verteenwoordig deur die kategorieë $̋ \xi \xi \omega$ en $̋ ้ \sigma \omega$ (so ook Wilckens 1980:93; en vgl Sellin 1986:215). Ook Murphy-O'Connor (1991:49) verwerp 'n dualistiese verklaring van Paulus se woorde hier deur daarop te wys dat hier nie sprake kan wees van die Griekse dualisme van liggaam en siel nie, omdat so 'n digotomie geen plek gehad het in Paulus se denke nie (kyk ook Danker 1989:78). En Martin (1986:91) verklaar in hierdie verband: "No such dichotomy is really to be found in Paul who, in this passage, comes closest to making the human being a hybrid of body and soul". Hierop kan geantwoord word dat dit eenvoudig nie bevredigend is om die gedagte van dualisme of 'n digotomie in die genoemde teks te 
verwerp bloot deur jou daarop te beroep dat dit nêrens elders by Paulus voorkom nie. Selfs al sou die aanname dus korrek wees dat dualistiese denke nie eie aan Paulus is nie, is dit nie voldoende rede om te aanvaar dat dit ook nie hier die geval kan wees nie, 'n moontlikheid wat klaarblyklik deur Martin toegegee word. Daar moet enersyds op gewys

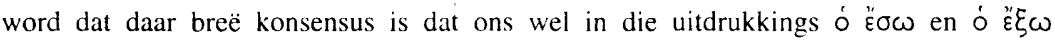
$\alpha$ äp interpretasie soos dié van Lietzmann en Barnett opgemerk word dat hoewel die innerlike mens waarvan hier sprake is, natuurlik veronderstel is om die nuwe mens in Christus te wees, daar nie in hierdie konteks in morele sin sprake is van die nuwe teenoor die oue, soos in die gevalle waar Paulus oor die Christen se nuwe menswees teenoor die oue gehandel het nie. Wat meer is, Paulus gryp met die uitspraak in 2 Korintiërs 4:16 op 4:713 terug (kyk Windisch 1970:151) waar daar veral in verse 10-13 sprake is van wat die apostel liggaamlik en daarom uiterlik deurmaak, al moet toegegee word dat hy as totale mens betrokke is by wat oor hom kom in diens van die evangelie. En hierby kan ook nog gevoeg word die opmerking van Walter (1996:56) dat die terme sigbaar/onsigbaar en tydelik/ewig "ganz deutlich hellenistische Diktion aufweist".

Beweeg 'n mens nou vanaf 2 Korintiërs 4:16 na 5:1 dan blyk daar meer as vol-

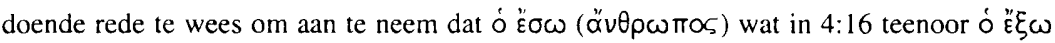

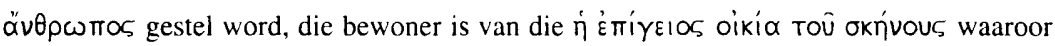

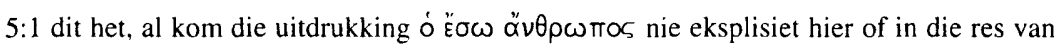
5:1-10 voor nie (kyk weer Bultmann 1968:202). Hierdie aanname berus daarop dat van

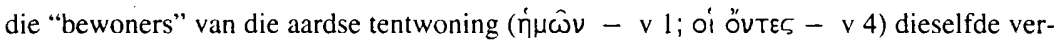

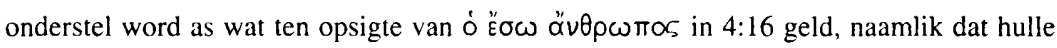

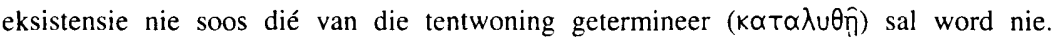
Hiermee hang saam dat oikía roû akńvous dan ook gesien moet word as semanties

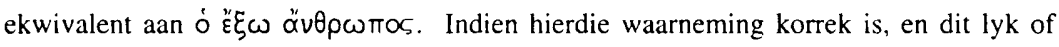
alles in hierdie rigting wys, kom dit daarop neer dat Paulus hier, in die woorde van Aune, die werklike persoon onderskei van die suiwer fisieke dimensie van menslike eksistensie, "so that this is essentially a pluralistic or dualistic appraisal of human nature..." (Aune 1995:301). 
Hierbo is reeds daarop gewys dat veral Schmithals (1969:249-252) 'n sterk saak daarvoor probeer uitmaak het dat hoewel Paulus in sy argumentvoering aansluit by die beskouings van die gnostici in Korinte, hy in verse $1-5$ nie ' $n$ dualistiese antropologie gepropageer het nie maar bloot teenoor die gnostici wou beklemtoon dat daar nie so iets moontlik is as dit waarna die gnostici gehunker het nie, naamlik dat die self deur die dood van die liggaam bevry moes word om 'n liggaamlose bestaan te kan voer (kyk ook weer Jewett 1971:265-267, 275-276). En hoewel hy Paulus se versugting in vers 8 om die "verblyf in die liggaam" te verlaat en "by die Here" te gaan woon, nie soos Bultmann net as "sehr nahe" aan Hellenisties-Gnostiese dualisme beskou nie maar dit "rein gnostisch" noem, oordeel hy dat dit nie beteken dat Paulus "hier in seinem Denken von der dualistischen Abwertung des Leibes gegenüber einem eigentlichen Selbst beeinflußt" is nie (Schmithals 1969:257). Al wat Paulus volgens hom met verse 6-8 wou doen, is om die gnostici se aanspraak dat hulle in Christus reeds van die liggaam verlos is, af te wys. Dit

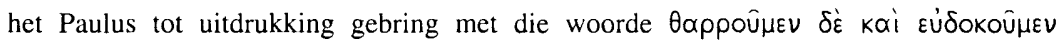
$\mu \hat{\alpha} \lambda \lambda$ ov, waarmee hy bedoel het dat "wir erst in Zuversicht leben und noch wünschen, nicht aber bereits besitzen" (Schmithals 1969:257). 'n Mens hoef nie die aanname te verwerp dat Paulus met hierdie perikoop onder andere wou stel dat die gelowige se bestaan "by die Here" 'n liggaamlike en daarom nie 'n liggaamlose bestaan sal wees nie. Dat hy hiermee ook hierdie vir hom vasstaande oortuiging teenoor 'n Gnostiese voorstelling wou handhaaf, hoef eweneens nie ernstig bevraagteken te word nie. Wat egter wel onaanneemlik lyk, is om op grond hiervan soos Schmithals, Jewett en ander te aanvaar dat wat hier aan dualistiese denke na vore kom, nie deur Paulus self gedeel is nie maar bloot argumentsonthalwe deur hom aan die orde gestel is. Die feit dat hierdie perikoop deel uitmaak van die sogenaamde "apostoliese apologie" (2:14-6:13; 7:2-4) in hierdie brief (kyk Pelser 1988:244-246; 1991:220-229) pleit na my oordeel juis daarvoor dat Paulus hom nie hiermee slegs afwysend teen andersdenkendes wou rig nie, maar ook positief uitdrukking wou gee aan die eskatologiese verwagting en versugting van die Christengelowige. Die indruk wat 'n mens dus uit hierdie perikoop sowel as die omliggende konteks kry, is dat Paulus hier inderdaad besig is met 'n apologie waarin hy sy oortuigings verwoord en nie met 'n polemiek waarin hy bloot teenstanders se argumente afwys nie. Al sou die feit dat hy hom oor hierdie sake uitlaat, deur teenstanders gepro- 
vokeer gewees het, is daar nie voldoende grond om te beweer dat wat Paulus hier betoog, nie sy eie oortuiging verteenwoordig nie.

Kyk 'n mens na die argumentvoering in hierdie perikoop, dan blyk dit dat daar wel oortuigende bewyse aangevoer kan word ten gunste van die aanname dat ons hier met dualistiese antropologiese denke by Paulus te make het (kyk ook Aune 1995:302). En dit geld nie alleen die argumentvoering nie, maar ook die stelwyse ten opsigte waarvan Walter (1996:57) sover gaan as om te sê dat dit "von vornherein hellenistisch geprägt" is. Eerstens word die tydelikheid en verganklikheid van die uiterlik fisieke bestaan van die mens beklemtoon deur daarna as oixía roû okñvous te verwys en dit as Ovnтós ( $v 4$ ) te kwalifiseer, in onderskeid van die menslike self wat klaarblyklik nie aan dieselfde tydelikheid en verganklikheid onderworpe is nie. Tweedens, hoewel hier nie sprake is van die intrinsieke boosheid van die liggaam of liggaamlike bestaan nie, word dit duidelik as minderwaardig voorgestel in vergelyking met die hemelse woning wat as

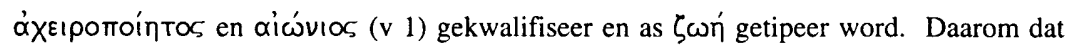

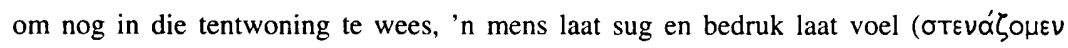

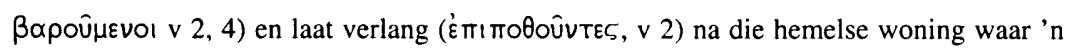
mens liewer ( $\mu \hat{\alpha} \lambda \lambda$ ov, $v 8)$ wil gaan woon as om in die aardse te bly woon. Dit stem opsigtelik baie ooreen met die begeerte wat Paulus in Filippense 1:23 uitgespreek het om heen te gaan en met Christus te wees, omdat hy van oortuiging was dat die lewe vry van die $\sigma \alpha \dot{\alpha} \rho \xi$ en by Christus, verreweg die beste is ( die "naak"-wees klaarblyklik op die moontlikheid dat die "self" van die mens sonder die fisieke liggaam kan bestaan of voortbestaan, ongeag die vraag of hierdie uitdrukking dui op die sogenaamde tussentoestand of nie. Dit lyk derhalwe onwaarskynlik dat hieronder iets anders verstaan kan word as die voorstelling nie alleen dat ' $n$ mens saamgestel is uit twee komponente, 'n innerlike en 'n uiterlike nie, maar ook dat die twee deur die dood van mekaar geskei raak, deurdat die eksistensie van laasgenoemde tot 'n einde kom maar dié van eersgenoemde nie. Hierdie interpretasie word ondersteun deur die wyse waarop hier gepraat word oor die self se alternatiewelike woon in die liggaam of by die Here. Die voorstelling dat die siel wanneer dit deur die liggaam se afsterwe van die liggaam bevry word, 'n toestand van naaktheid betree, dit wil sê 'n toestand van selfstandige bestaan waarna ook gehunker is, was bekend in Grieks-filosofiese kringe, veral by Plato 
(kyk vir bewysmateriaal Windisch 1970:164-165; Bultmann 1967:299-200; Wolff 1989: 110). Al sou 'n mens ook aanvaar dat Paulus met die verwysing na die naakwees met die gnostici polemiseer en juis betoog dat die gelowige wanneer die tentwoning afgebreek of vernietig word, nie naak daar sal staan nie maar terstond met die woning uit die hemel beklee sal word, neem dit nog nie weg dat hy hiermee iets tot uitdrukking gebring het van die gedagte dat die self gekontinueer sal word en nie soos die aardse liggaam tot niet sal gaan nie. Die feit dat die gedagte van naak bevind te word vir hom duidelik 'n angswekkende gedagte blyk te gewees het (Walter 1996:58), is waarskynlik 'n verdere aanduiding dat hy 'n liggaamlose bestaan van die self nie as ' $n$ volslae onmoontlikheid gesien het nie. Iemand soos Talbert (1989:161) is selfs nog stelliger oor die saak deur die mening uit te spreek dat dit lyk of Paulus daarmee rekening gehou het dat dié wat voor die paroesie sou sterf, 'n periode van naaktheid (tussentoestand?) sou deurmaak waarna dan aan hulle opstandingsliggame gegee sal word. Dit sou natuurlik soveel te meer die geval kon wees as dit Paulus se gedagte was dat die vernietiging van die aardse woning reeds by die fisieke dood plaasvind en nie eers by die paroesie nie (so Bultmann 1967: 305). Dit alles in ag genome, blyk daar nietemin in verse 2-4 voldoende bewys te wees dat die moontlikheid van 'n liggaamlose bestaan van die self vir hom 'n onaanvaarbare moontlikheid was, aangesien hy juis daarvoor teruggedeins het en die ernstige begeerte uitgespreek het dat dit deur oorkleding met die hemelse woning verhoed mag word. Vierdens is dit nogtans opvallend dat hoewel hy in 1 Korintiërs 15:44 uitdruklik ook van

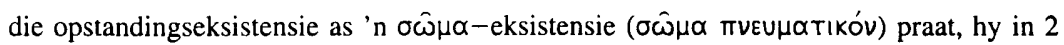
Korintiërs 5:6-8, waarin dit gaan oor die alternatiewelike hiér woon of dáár woon, nêrens hierdie term vir die toekomstige of hemelse eksistensie gebruik nie. Terwyl hy dus ten opsigte van die aardse eksistensie by herhaling $\sigma \hat{\omega} \mu \alpha$ gebruik, is die hemelse teenhanger daarvan nie die inwoning in 'n opstanding- $\sigma \hat{\omega} \mu \alpha$ nie, maar mpòs tóv kúpıov. Moet dit 'n mens laat vermoed dat hy sedert 1 Korintiërs 15 meer "Hellenisties" oor die saak begin dink het en die voorstelling van die Korintiërs met hulle begin deel het (so Walter 1996:59)? Hoe onaanvaarbaar so 'n vermoede ook al vir baie mag klink, feit is dat die ontbreking van $\sigma \hat{\omega} \mu \alpha$ hier, om die minste te sê, verdag voorkom. Aan die ander kant moet ' $n$ mens toegee dat die hemelse oikía waarvan in verse 1-2 sprake is, op die hemelse bestaanswyse moet dui en daarom op meer dui as net die feit van by die Here te 
woon. Hoe dit ook al sy, dit lyk of daar in die res van die perikoop voldoende aanwysers is vir die aanname dat Paulus hom wel in hierdie perikoop dualisties oor menswees uitgelaat het.

Moet ' $n$ mens nou die dualistiese antropologie wat in bogenoemde perikoop aan die orde is as ' $n$ geïsoleerde geval by Paulus beskou en dit daarom nie te ernstig opneem nie, of is daar by hom ook ander uitsprake met hierdie strekking aanwysbaar? Hiervoor sal ons na 'n paar van die voor die hand liggendste gevalle moet kyk. As nog ander gevalle ten opsigte waarvan daar 'n vermoede van dualisme bestaan, is hierbo ook verwys na Romeine 6:6; 7:24; 8:10-11 en 1 Korintiërs 5:3-5; 9:27; 15:50. Wat die Romeine gevalle betref, is sake nie so voor die handliggend nie, hoewel minstens gesê kan word dat hulle verdag voorkom. Die rede hiervoor is dat die menslike $\sigma \hat{\omega} \mu \alpha$ in al hierdie

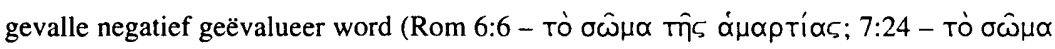

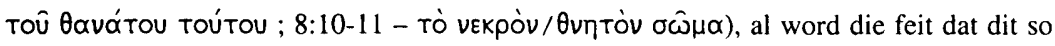
is telkens toegeskryf aan die sonde (kyk Conzelmann 1968:199; Schnelle 1991:66). Neem 'n mens egter in aanmerking dat Paulus volgens Romeine 5:12 die oortuiging gedeel het dat die sonde met die oortreding van die eerste mens in die wêreld gekom het en sedertdien die lewe van die mens beheers het (Rom 5:17), dan kan met reg gesê word dat hy in elk geval die meeste van die tyd negatief oor die liggaam moet gedink het. En hierdie waarneming pleit weer sterk vir die vermoede dat ons hier ook met dualistiese gedagtes te make het. Die meeste eksegete stem met Bultmann (1968:204) saam dat dit

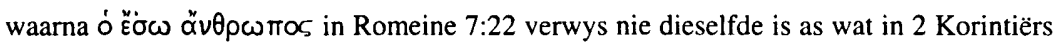
4:16 aan die orde is nie, aangesien dit nie hier (in Rom 7:22) gaan om die self wat teenoor die liggaam gestel word nie, maar om die eintlike self wat teenoor die aan die sonde vervalle self gestel word (kyk ook Perkins 1986:519-520; Markschies 1994:4; anders Boyarin 1994:84). Hierdie oortuiging het ook vir Käsemann (1974:198) laat kies teen wat hy noem die "gängige Auslegung" waarvolgens 'n antropologiese dualisme in Romeine 7:14-25 ingelees word. Maar dan moet hierteenoor gewys word op die meriete van die argument wat Boyarin (1994:62) aanvoer ten gunste van die aanname dat hierdie perikoop wel 'n dualistiese strekking het, naamlik dat daar in Romeine 7:22-23 nie alleen 'n onderskeid getref word tussen die innerlike self en die lede van die liggaam nie, maar ook dat gestel word dat daar vanuit die lede van die liggaam stryd teen die self gevoer 
word. Indien hierdie aanname voldoende grond het, beteken dit dat die noodroep in

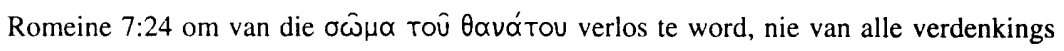
van dualisme gevrywaar kan word nie. En al sê Bultmann (1968:201) dat 7:24 nie die bevryding van die $\sigma \hat{\omega} \mu \alpha$ "überhaupt" in gedagte het nie, maar van die "von der oáp $\xi$ durchwalteten $\sigma \hat{\omega} \mu \alpha$ ", en daarom in die grond van die saak van die $\sigma \alpha \dot{\rho} \xi$, beteken dit nogtans dat hierdie liggaam gestel word teenoor die self wat roep om daarvan bevry te word. Hierdie gedagte word versterk as Bultmann (1968:202) dit reg het dat die hoop op

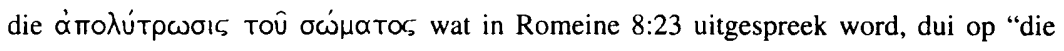
Erlösung vom sarkischen Leibe, d. h. von der oápร". Dit is ook meer as net interessant dat Wilckens (1980:95) wat in 'n voetnoot by Romeine 7:24 verwys na 'n "eindrückliche Paralleie" in die Corpus Hermeticum, tog nog met stelligheid beweer dat dit nie in hierdie noodroep gaan om "die Klage des hellenistischen Menschen über seine Vergänglichkeit, die in seiner irdischen Leiblichkeit verursacht" is nie, maar om die doodvervallenheid van die liggaam as gevolg van die sonde. Hiermee erken hy minstens dat daar 'n tipiese Hellenistiese dualisme agter Paulus se woorde skuil, iets wat 'n mens dan laat wonder of hierdie woorde van alle dualisme gesuiwer kan wees. Na my oordeel is Jewett (1971: 294) eerder gelyk te gee wanneer hy sê dat die idee wat met hierdie noodroep uitgedruk word, volledig Gnosties is, aangesien hier nie alleen gevra word vir die verlossing van die

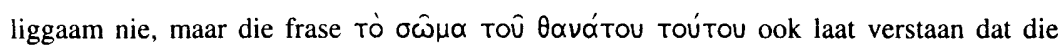
liggaam die oorsaak van die mens se dood is.

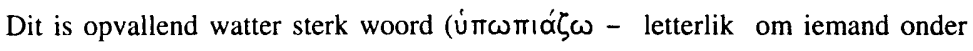
die oog, blouoog te slaan) Paulus in 1 Korintiërs 9:27 gebruik om uitdrukking te gee aan die beheersing en diensbaarmaking waaraan hy sy liggaam onderwerp. In die konteks waarin die uitdrukking voorkom, sou dit nie te vergesog wees om dit so te verstaan dat Paulus sy liggaam as 't ware hier as 'n opponent voorstel nie. Dit het Jewett (1971:256) laat vermoed dat ons ook hier met 'n geval te doen het waar Paulus op Gnosties-dualistiese wyse na die liggaam verwys het. Maar dan verklaar Jewett dit ook hier as deur die gnostici geprovokeer deurdat Paulus teenoor die gnostici se misbruik van die liggaam vir allerlei genietinge, wou stel dat die liggaam onder bedwang gehou moet word. Die saak is egter te onseker om bloot vanuit die konteks tot 'n dualistiese interpretasie te kom,

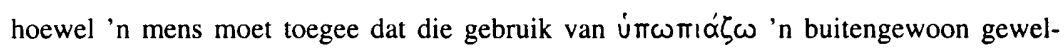


dadige indruk maak en 'n mens laat wonder of die liggaam nie hier in 'n negatiewe lig gestel word nie.

Dit lyk of die saak anders daar uitsien in 1 Korintiërs 5:1-5 waar Paulus handel oor die geval van die persoon wat met sy stiefma saamgeleef het en waarin hy twee uitsprake makk wat oorweging verdien. Die eerste vind ons in vers 3 waar hy sê dat hy

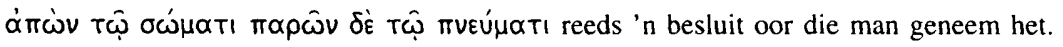
Hoewel hierdie woorde normaalweg bloot kan beteken dat hy "in die gees", dit wil sê in "wensende" sin teenwoordig was, wil dit tog voorkom of hy hiermee iets meer tot uitdrukking wou bring. Dit blyk daaruit dat hy in vers 4 hierdie woorde nader omskryf

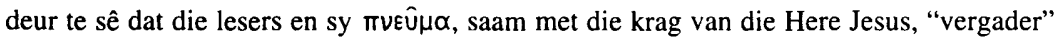
het om die man aan die Satan oor te gee. Hiermee bedoel hy klaarblyklik nie dat hy bloot "in sy gedagtes" teenwoordig was nie, maar dat sy $\pi v \varepsilon u ̄ \mu \alpha$ as 'n werksame "mag" teen-

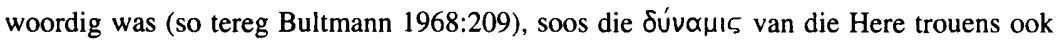
'n teenwoordige werklikheid was. Hierdie interpretasie word ook deur Meeks (1983:128) ondersteun wanneer hy sê dat die frase $\dot{\omega} \zeta$ $\pi \alpha \rho \hat{\omega} v$ in vers 3 nie met "as if present" vertaal moet word nie, en dan verklaar: "It is the effectiveness of his real presence ("in spirit') that Paul insists on in the striking phrase 'you and my spirit' (vs. 4)". Dit impliseer beslis meer as wat normaalweg met "in die gees" bedoel word, waaruit afgelei kan word dat Paulus van oordeel was dat die innerlike self selfstandig en los van die liggaam kan optree. Hierdie teenoormekaarstelling van die innerlike self en die liggaam word nog sterker tot uitdrukking gebring in die volgende woorde van vers $5:$ દiऽ ö $\lambda \varepsilon \theta \rho o v$

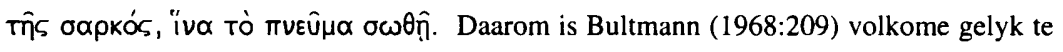
gee wanneer hy ten opsigte van hierdie woorde bevestigend antwoord op die vraag: "Ist

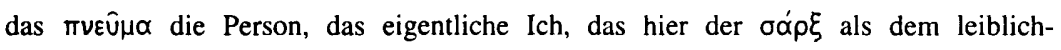
körperlichen Leben (wie 2. Kor 5,1ff dem $\sigma \hat{\omega} \mu \alpha$ ) gegenübergestellt wird"? Voeg hierby

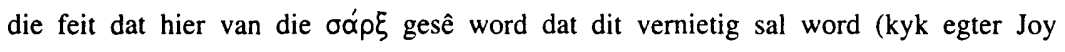

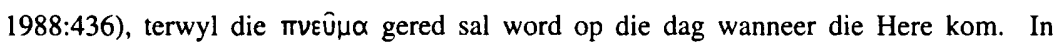
hierdie verband het Boyarin (1994:61) daarop gewys dat hierdie voorstelling verskil van die Rabbynse eskatologiese verwagting waarvolgens die siel en die liggaam op die dag van gerig verenig sal word vir redding of vernietiging. Dieselfde geld ook van die eskatologiese verwagting wat in die apokaliptiek gekoester is en ten opsigte waarvan 
Russell (1964:375) die volgende opmerking maak: "As writers in the Hebrew tradition which regarded the body as an essential aspect of personality, the apocalyptists believed that survival after death could not be expressed ultimately in terms of soul or spirit apart from body". Dit lyk dus of daar met alle reg gesê kan word dat daar ook in hierdie woorde van Paulus minstens iets deurskemer van die Hellenistiese voorstelling waarvolgens die gees of die siel van die liggaam bevry sal word (kyk Weiss 1970:132), al is dit so dat, soos uit 2 Korintiërs 5:1-5 en elders blyk, 'n liggaamlose bestaan na die dood vir hom ondenkbaar was. Dit is verder betekenisvol dat Bultmann die teenoormekaarstelling van die innerlike self en die liggaamlike hier in 1 Korintiërs 5:3-5 beskou as in ooreenstemming met wat in 2 Korintiërs 5:1-10 die geval is (anders o a Joy 1988:432434). Hiermee onderskryf hy die hierbo beredeneerde bevinding dat Paulus hom ook in laasgenoemde geval die menslike $\pi v \varepsilon u \hat{\mu \alpha} \alpha$ en $\sigma \hat{\omega} \mu \alpha / \sigma \alpha \dot{\rho} \xi$ in 'n dualistiese verhouding tot mekaar voorgestel het (so tereg ook Boyarin 1994:61), selfs al sou Jewett (1971:124) dit reg hê dat Paulus onbewus was van die teologiese implikasies van sy uitspraak op hierdie punt, 'n aanname wat egter vir my onwaarskynlik lyk.

Nog 'n geval wat aandag verdien, vind ons in Paulus se woorde in 2 Korintiërs

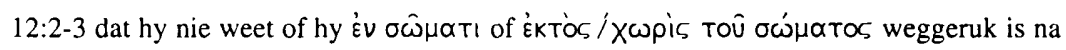
die derde hemel toe nie. Ongeag die vraag of die gedagte van Éxtós/Xwpis toû

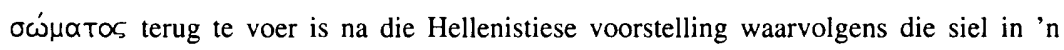
toestand van ekstase die liggaam verlaat en weer na die liggaam terugkeer (so bv Windisch 1970:374-375; Wolff 1989:243), is dit nie te betwyfel dat die self ook hier met die liggaam gekontrasteer word of daarvan onderskei word nie (so tereg Aune 1995:303; kyk ook Boyarin 1994:61). Die feit dat Paulus twee keer sê dat hy nie weet of die wegrukking in of buite die liggaam geskied het nie, dui volgens Bultmann daarop dat hy met die moontlikheid rekening gehou het "daß sich das Ich schon im gegenwärtigen Leben vom $\sigma \omega \hat{\mu} \alpha$ lösen kann, und dieses $\sigma \omega \hat{\mu \alpha}$ kann dann doch nur der körperliche Leib sein" (Bultmann 1968:203). Schmithals wat van oordeel is dat Paulus ook in hierdie geval reageer op aansprake van die gnostici, verskil egter van bogenoemde aanname van

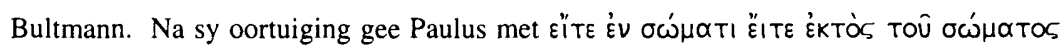

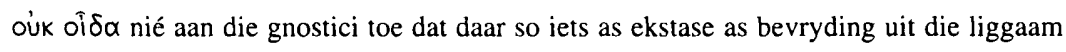
moontlik is nie. Wat hy wel hiermee wil sê, is: "Ich weiß nicht, wieso euch das interes- 


\section{Dualistiese antropologie by Paulus?}

siert. Ja, ich weiß nicht einmal, wie ihr euch das überhaupt vorstellt" (Schmithals 1969:204). Vir hierdie aanname van Schmithals blyk daar nie voldoende grond te wees nie, want hoewel dit so is dat Paulus hier op aansprake van die teenstanders reageer, is daar niks in die konteks wat daarop dui dat hy nie die gedagte van ekstase in die sin van die self wat die liggaam verlaat, gedeel het nie. Dat die woorde "ek weet nie" soos deur Schmithals geïnterpreteer moet word, lyk ook nie aanvaarbaar nie, omdat die antwoord ó

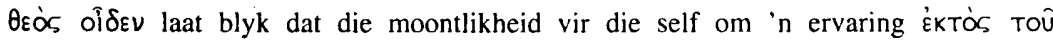

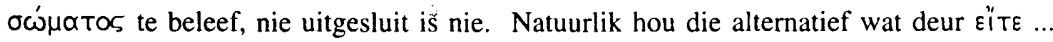

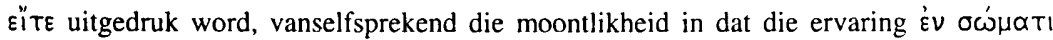
kon geskied het, wat op sy beurt daarop dui dat so 'n ervaring ook vir die liggaam moontlik was. Hierdie feit verander egter niks daaraan dat die self en die liggaam hier op dualistiese wyse as van mekaar verwyderbaar voorgestel word nie.

\section{ANTROPOLOGIESE INKONSEKWENTHEID BY PAULUS?}

\subsection{Korintiërs 15:35-54}

Om mee te begin, is dit nodig om te herinner aan die oordeel van Crossan (1998:XXIX$\mathrm{XXX}$ ) dat Paulus hom in sy betoog oor die opstanding in bogenoemde gedeelte aan ' $\mathrm{n}$ inkonsekwentheid skuldig gemak het, deur aan die een kant die opstanding te verduidelik aan die hand van die metafoor van die saadkorrel en die plant (verse 36-38), wat kontinuïteit veronderstel, en dit aan die ander kant te verduidelik deur te wys op die verskil tussen aardse en hemelse liggame (verse 40-44), wat diskontinuïteit veronderstel. Sonder om die saak vooruit te loop, wil dit met die eerste oogopslag wel lyk of die twee wyses waarop Paulus die saak probeer verduidelik het, nie maklik met mekaar te harmoniseer is nie. Of dit inderdaad die geval is, sal egter deur 'n noukeuriger ondersoek van sy betoog bepaal moet word.

Wat die metafoor van die saadkorrel en die plant betref, is die saak ingewikkelder as wat dit op die oog af mag voorkom, afgesien van die kwessie of Paulus daarmee 'n antwoord op een (Conzelmann 1969:332: Sellin 1986:72; Wolff 1996:402) of op twee vrae ( $\pi \omega \hat{s}$, поí, v 35) wou gee (Jeremias 1966a:287; 1966b:304-305; Sider 1975:428- 
429; Quast 1994:100-101). Vra 'n mens na die veronderstelde betekenis van hierdie metafoor, word jy weldra bewus van 'n bepaalde verstaansprobleem. Dit is geleë in wat 'n mens kan noem die verskynsel van beide eendersheid en andersheid wat deur die metafoor gedra word en wat deur Crossan uitgedruk word met die woorde "totally the same and absolutely different" (1998:XXIX). As ek Crossan reg verstaan, wil hy hiermee sê dat daar enersyds ' $n$ bepaalde kontinuitteit of identiteit is tussen die saadkorrel en die plant, maar dat die twee andersyds minstens in voorkoms totaal van mekaar verskil. Terwyl daar oor die aspek van verskil opsigtelik geen twyfel bestaan nie, is dit nodig om noukeurig te oorweeg of 'n mens so stellig soos Crossan kan praat van 'n "unbroken material and physical continuity" tussen die saadkorrel en die plant (Crossan 1998:XXX, my beklemtoning). Om dit te sê van die verhouding tussen 'n saadkorrel en die plant wat daaruit voortkom, is biologies gesproke volkome juis. Maar dit is 'n vraag of die klem wat Paulus daarop lê dat die saadkorrel nie tot lewe kan uitspruit as dit nie eers gesterf het

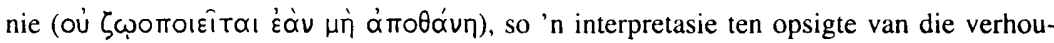
ding tussen die aardse en die opgestane bestaanswyse van die mens toelaat.

Sellin het, onder andere met ' $n$ beroep op 'n hele ry prominente vakgenote, beklemtoon dat die gedagte van diskontinuïteit juis beslissend in die kringloop van sterwe en wording in hierdie metafoor opgesluit lê. "Das Verhältnis von Saat und Pflanze wird gerade nicht im Sinne des Keim-Begriffs verstanden, sondern als eine Neuschöpfung Gottes im Sinne eines Wunders" (Sellin 1986:214). Daar moet toegegee word dat daar geen aanduiding is dat die tot-nuwe-lewe-kom van die gestorwe mens waarna die metafoor veronderstel is om te verwys, as 'n selfgroei-proses (self-opstanding) voorgestel

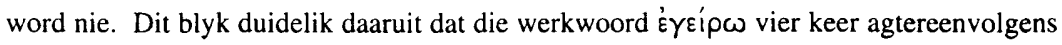
in verse 42-44 as korrelaat vir бாعipw aangewend word, iets wat klaarblyklik daarop dui dat die totstandkoming van die opstandingsliggaam alleen deur 'n opwekkings- of nuwe skeppingsdaad van God moontlik is. Maar dan moet ook daarop gewys word dat deur

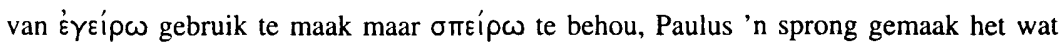

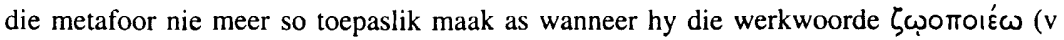

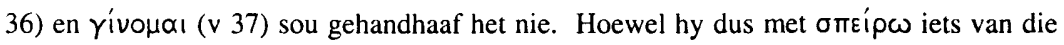
metafoor behou het, wou hy met die invoer van غ̇ $\gamma \varepsilon i p \omega$ hier reeds die opstanding as 'n opwekkingsdaad van God op die voorgrond plaas. En tog kan 'n mens, ten spyte van 
hierdie klem op die gedagte van opwekking, nie anders as om die indruk te kry dat Paulus met hierdie metafoor tot uitdrukking wou bring dat daar 'n bepaalde kontinuïteit of identiteit tussen saadkorrel en plant, of dan tussen die aardse en die opstandingsmens bestaan nie. Dit wil sê dat ten spyte van die feit dat daar in die metafoor gepraat word van sterwe, die identiteit tussen die aardse en opgewekte mens nie daarmee geloën word of verlore gaan nie: "Doch verliert das Sterbende niemals seine identität" (Strobel 1989:257; kyk ook Wolff 1996:403). Of om dit in die woorde van Talbert (1989:100) te stel: "The apostle's point is that the plant that emerges is the same being but has a different body. There is continuity in the life-principle, but the form of its expression changes" (my beklemtoning). Aan hierdie oortuiging het ook Sider (1975:435) uitdrukking gegee deur daarop te wys dat die feit dat dit die verganklike liggaam is wat as onverganklike liggaam opgewek word, beteken dat daar "genuine bodily continuity" is, maar ook "significant discontinuity". Dit alles laat 'n mens vermoed dat Paulus van hierdie metafoor gebruik gemaak het juis omdat hy dit as uiters geskik beskou het om uitdrukking te gee aan beide die elemente van identies en nie-identies wat daar in hierdie verhouding opgesluit lê: "The imagery effectively communicates both the continuity and the transformation that exist between what is sown and what is raised" (Quast 1994:97; vgl ook Sider 1975:432).

Hierteenoor sien die saak heeltemal anders daaruit wanneer Paulus met die andersoortigheid van hemelse en aardse liggame as vertrekpunt (v 40) die radikale verskil

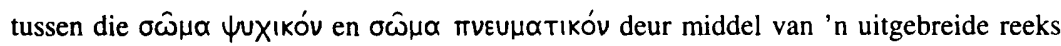
van kontrasterende kwalifikasies illustreer en beklemtoon: $\phi \theta 0 \rho \alpha-\alpha \dot{\phi} \theta \alpha \rho \sigma i ́ \alpha ; \dot{\alpha} \tau ı i^{\alpha} \alpha-$

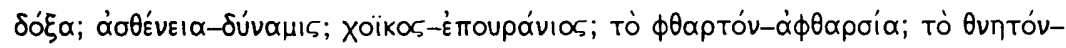
¿ंबavaoia (verse 42-53). Hiermee stel hy hierdie twee bestaanswyses as volledig diskontinu en wesenlik verskillend voor en onderstreep hy dit ook nog met die resumerende uitspraak dat vlees en bloed, dit wil sê die mens as aards-verganklike wese, nie aan die koninkryk van God deel sal kry nie, net so min as wat die verganklike (í $\phi \theta \circ \rho \alpha ́)$ aan die onverganklike ( $\dot{\eta} \alpha \dot{\phi} \phi \alpha \rho \sigma i \alpha)$ deel kan kry. "V.44b-50 läuft darauf hinaus, daß es zwischen Adam-Existenz und Christus-Pneuma-Existenz keine Kontinuität gibt, keine anthropologische Konstante" (Sellin 1986:223). Al hoef die uitspraak in vers 50 nie noodwendig aan dualistiese beïnvloeding, Hellenisties of Joods, toegeskryf te word nie, 
kan nie ontken word dat die aards-liggaamlike van menswees hiermee gediskwalifiseer word as nie geskik vir die opstandingslewe nie en daarom in terme daarvan negatief, hoewel nie as inherent boos nie, beoordeel word. En dit is juis hierdie onderwaardering van die aards-liggaamlike wat verskeie persone tot die oortuiging gebring het dat Paulus ook in hierdie konteks dualisties oor menswees gedink het.

Hierdie onvermoë van vlees en bloed om aan die koninkryk deel te kry, word ook

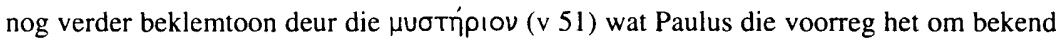
te maak, naamlik dat dié wat by die paroesie nog lewend sal wees en derhalwe nie saam

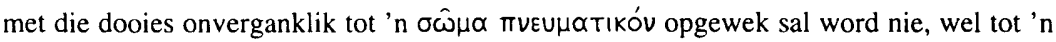

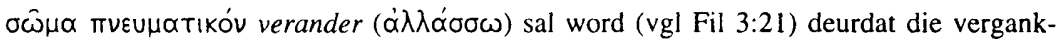

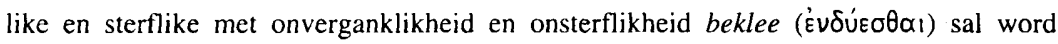
(verse 51-53). Dit herinner natuurlik aan die taal van 2 Korintiërs 5:2-4 waarvolgens die oorgang na die nuwe bestaanswyse ook bewerkstellig sal word deur die bekleding met die hemelse woning. Daar is egter 'n opmerklike verskil en dit is dat terwyl dit in 2 Korin-

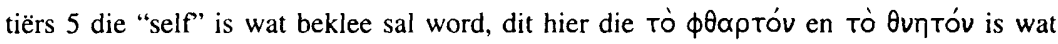
onderskeidelik met $\dot{\alpha} \phi \theta \alpha \rho \sigma i \alpha$ en $\alpha \dot{\theta} \alpha v \alpha \sigma i \alpha$ beklee sal word. Maar hoe moet 'n mens

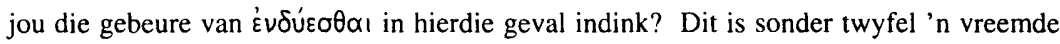
gebruik van die woord. Daarom is Sellin (1986:225) reg as hy sê dat hierdie woord "freilich nicht recht passend" is om die verandering vanaf die sterflike na die onsterflike bestaanswyse mee te beskryf nie, hoewel hy van mening is dat die keuse van die woord ook in hierdie geval op die Korintiese antropologie gegrond word wat weer deur die Aleksandryns-Joodse wysheidsteologie beïnvloed is (kyk ook Sellin 1986: 72-73,88,189). Aan die ander kant is dit nie onmoontlik dat Paulus om ' $n$ bepaalde rede doelbewus vir

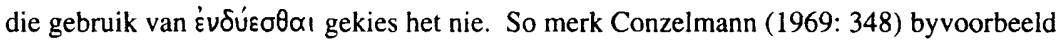

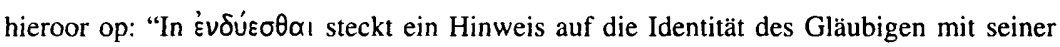
künftigen Existenz". En hiermee stem ook Sider (1975:437) saam omdat hy van oordeel is dat die viervoudige gebruik van Toûto in verse 53-54 dui op die bekleding van die

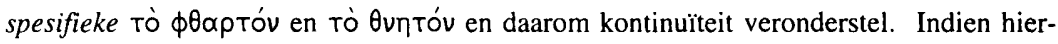
die waarneming korrek is, sal dit beteken dat wat Paulus hiermee wou sê, na alle waarskynlikheid nie verskil van wat hy in 2 Korintiërs 5:4 tot uitdrukking gebring het met ...

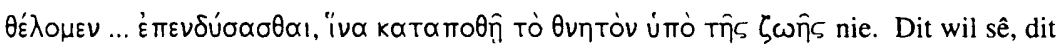


gaan dan ook hiér om die self wie se sterflike uiterlike bestaanswyse deur 'n onsterflike vervang sal word deurdat laasgenoemde (soos 'n kledingstuk) bo-oor eersgenoemde aangetrek sal word. Sou dit korrek wees, en dit lyk nie sonder meriete nie, sou dit natuurlik Paulus se argument in verband met die opstanding hier in dieselfde dualistiese kader plaas as sy uitsprake in 2 Korintiërs 5:1-4 oor hoe die aardse bestaanswyse met die hemelse vervang sal word.

Die slotsom waartoe so pas gekom is, mag die indruk skep dat Crossan se bevinding van "totally the same and absolutely different" en veral van 'n "unbroken material and physical continuity" ten opsigte van die verhouding tussen die saadkorrel en die plant

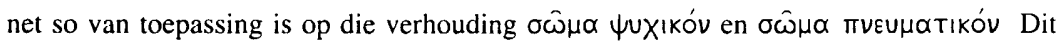
kan egter nie, aangesien daar soos reeds aangedui duidelik geen sprake skyn te wees van 'n materiële kontinuïteit tussen die genoemde twee $\sigma \omega \omega_{\alpha} \alpha \alpha$ nie. Die absolute verskil tussen aardse en hemelse liggame wat as vergelykingspunt gebruik word om die verskil

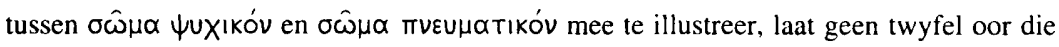

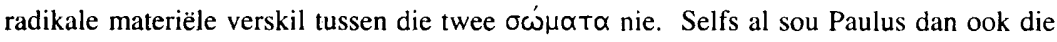
kontinuering van die self in gedagte gehad het, kan daar nie twyfel daaroor wees dat hy hom die twee bestaanswyses van die self as radikaal verskillend voorgestel het nie. Dit lyk dus of ' $n$ mens met Crossan sal moet saamstem dat Paulus in sy argumentasie oor die opstanding in 1 Korintiërs 15 nie antropologies konsekwent geredeneer het nie. Maar dan moet ' $n$ mens hierby sê dat hierdie inkonsekwensie in die algemeen geld van Paulus se uitsprake oor die toekomseksistensie van die gelowige. Sonder om op hierdie punt die veel gedebatteerde kwessie of daar ontwikkeling in Paulus se eskatologie plaasgevind het op die tafel te plaas (kyk o a Pelser 1986; Walter 1996:63-64), kan nie ontken word dat dit moeilik is om ' $n$ eenduidige beeld te vorm van wat hy werklik in verband met die gelowige se toekomsverwagting gedink het nie. Volgens 1 Tessalonisense 4:16-17 sal die dooies by die paroesie klaarblyklik herkenbaar opstaan en saam met die nog lewendes die lug in gevoer word om altyd by die Here te wees, en dit sonder dat daar daarvan sprake is dat eersgenoemdes se opstandingseksistensie andersoortig as die aardse sal wees of dat laasgenoemdes verander sal word soos wat in 1 Korintiërs 15 van hulle gesê word. Volgens Filippense 1:23 lyk dit of die gelowige onmiddellik na afsterwe by die Here sal wees, sonder egter dat gesê word in watter vorm dit sal gebeur. In 2 Korintiërs 5 , ten 
slotte, word die vervanging van die aards-tydelike bestaanswyse met 'n hemels-ewige verwag, met die moontlikheid, hoe onaanvaarbaar ook al vir Paulus, dat die self 'n oomblik of 'n periode van naaktheid kan ervaar, blykbaar nie uitgesluit nie.

\subsection{Galasiërs 3:28}

Wat betref Crossan se oordeel dat Paulus inkonsekwent was met die opheffing van die verskille tussen Jood en Griek, slaaf en vry, man en vrou, soos in Galasiërs 3:28 aangekondig, moet hier met slegs 'n paar opmerkings volstaan word, aangesien die Pauliniese beskouing oor beide die posisie van die vrou en die slaaf 'n afsonderlike en omvattende ondersoek regverdig. Wat die vroue betref, het ek in 'n vroeëre ondersoek (Pelser 1976) probeer aantoon dat hy nie alleen die positiewe gesindheid wat Jesus teenoor vroue geopenbaar het, voortgesit het nie, maar ook in baie opsigte daadwerklik aan vroue gelyke status toegeken het in die werk vir die evangelie. Wat hy in 1 Korintiërs 7 in verband met die huwelik en die man-vrou verhouding sê, kan werklik nie geïnterpreteer word as sou hy hier net spirituele gelykheid aan die vrou toeken en nie ook daadwerklike fisieke gelykheid nie. Maar dan moet ' $n$ mens toegee dat dit wil voorkom of hy in 1 Korintiërs 11:3-10 alles wat hy in Galasiërs 3:28 oor die gelykheid van man en vrou gesê het, tot niet maak, hoewel hy die saak in verse 11 en 12 weer in 'n mate herstel. Dat ons egter hier te make het met ' $n$ besondere situasie rakende die samekoms van die gemeente waaroor daar eksegeties baie moeilik uitsluitsel gegee kan word, is nie te betwyfel nie (kyk o a Schrage 1982:215). Maar ten spyte hiervan blyk daar na my oordeel in elk geval nie voldoende grond te wees om te beweer dat Paulus met hierdie perikoop 'n streep getrek het deur die oortuiging wat hy in Galasiërs 3:28 uitgespreek het nie. Dit geld ook die sogenaamde swyggebod in 1 Korintiërs 14:34-36. In die ondersoek waarna ek hierbo verwys het, het ek my geskaar by dié wat van oordeel is dat ons in hierdie geval te doen het met ' $n$ verbod wat nie versoenbaar is met die gesindheid wat Paulus klaarblyklik teenoor vroue geopenbaar het nie en dat dit derhalwe as ' $n$ interpolasie gesien moet word. Ek staan steeds by hierdie standpunt saam met 'n groeiende aantal eksegete. Dit beteken dat ook nie hierdie swyggebod gebruik kan word as bewysmateriaal dat Paulus oor die gelykheid van die vrou teruggekrabbel het nie. Wat 'n mens gewaar word van die gees wat in die Paulusbriewe jeens vroue geadem word, kan daarom kwalik geïnterpreteer 
word as sou dit net op spirituele gelykheid vir vroue neerkom. Dat hy in 'n sekere sin die onderskeid tussen die geslagte gehandhaaf het, hoef nie gedebatteer te word nie. Dat hy egter daarmee die vrou se fisieke ondergeskiktheid aan die man probeer handhaaf het, moet nog bewys word. Die outeurs van Efesiërs en Kolossense het met hulle huis-tafels in elk geval baie swakker as Paulus gevaar wat hierdie saak betref, en so ook die outeur van die Pastorale Briewe (veral in 1 Tim 2:11-15). En dit is nie al nie, deur in Paulus se naam te skrywe, het hierdie outeurs tot op groot hoogte daartoe bygedra dat Paulus onverdiend en onregverdiglik die skuld gekry het vir die minderwaardige posisie wat tot vandag toe aan vroue in kerk en samelewing toegeken is.

Soos bekend, is daar nêrens in Paulus se briewe enige aanduiding dat hy hom teen slawerny uitgespreek het of vir die vrylating van slawe beywer het nie, hoewel met reg gesê kan word dat die wyse waarop hy hom in verband met Onesimus tot Filemon gerig het, die vrylating van Onesimus minstens gesuggereer het. Vanweë die vertaalprobleem wat 1 Korintiërs 7:21 oplewer, is dit nie moontlik om uit te maak hoe Paulus oor slawerny gedink het nie. Was hy van oordeel dat elke geleentheid tot vrywording aangegryp moes word of het hy gereken dat dit in die lig van die gedrongenheid (ó kaıpòs

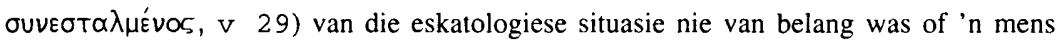
slaaf of vry was nie? Indien eersgenoemde interpretasie as die waarskynlikste beskou sou moes word, sou dit in elk geval nog nie veel sê oor die vraag of hy slawerny as 'n aanvaarbare sosiale instelling of as ' $n$ euwel beskou het nie. Aan die ander kant kan sy swye oor die saak kwalik as goedkeuring verstaan word of as aanduiding dat hy, soos Crossan oordeel, die opheffing van die verskil tussen slaaf en vry bloot as van spirituele aard beskou het. Daar kan geen onsekerheid bestaan oor die nadelige en selfs katastrofiese gevolge wat dit vir beide Paulus en die jong Christendom sou hê indien hy hom deur woord of daad vir die vrylating van slawe selfs in Christelike kring sou beywer het nie. Dat hy dus sy oortuiging dat daar in Christus nie meer slaaf of vry is nie, nie na die strate van die Romeinse stede toe geneem het nie, beteken nie dat hy halfpad in sy oortuiging vasgesteek het nie. Hy sou dit sekerlik in dieselfde mate as wat hy dit as 'n spirituele werklikheid beskou het, ook as 'n fisieke werklikheid deurgevoer wou sien. Sy tyd en sy wêreld het hom dit egter eenvoudig nie toegelaat nie. Hy het in elk geval niks slegter gevaar as die Christendom na hom wat vir agtien eeue lank onder aansienlik 
minder bedreigende omstandighede slawerny sienderoë laat voortduur het en ook self toegepas het nie.

\section{SAMEVATTING}

Ek meen dat met die voorgaande ondersoek voldoende bewys gelewer is dat Paulus se antropologie beslis dualistiese trekke vertoon, deurdat die mens voorgestel word as saamgestel uit 'n (kontinuerende) innerlike self en 'n (verganklike) uiterlik liggaamlike. Dit het egter eweneens geblyk dat Boyarin dit reg het dat hierdie dualisme as gematig getipeer moet word omdat 'n mens nêrens die indruk kry dat die liggaam of die uiterlike van die mens as intrinsiek boos en as gevangenis van die self beskou is nie. Trouens 'n liggaamlose bestaan was vir Paulus ondenkbaar, soos duidelik te sien is in veral 1 Korintiërs 15:35-54 en 2 Korintiërs 5:1-10 waar hy laat blyk hoe hy hom die hemelse bestaanswyse van die gelowige voorgestel het, naamlik dat dit soos die aardse ook 'n liggaamlike bestaanswyse sal wees. Hiermee het hy hom beslis gedistansieer van die sogenaamd Gnostiese gedagte dat die hemelse eksistensie sou bestaan uit die voortlewe van die siel of die gees in liggaamlose vryheid. Wat hiermee saamhang en besonder opvallend is, is dat terwyl daar by hom aanduidings is van die kontinuering van die self na die dood, Paulus nêrens die gedagte van die onsterflikheid van die siel propageer nie. Dit moet na alle waarskynlikheid juis daaraan toegeskryf word dat 'n liggaamlose (voort)bestaan van die self vir hom só onaanvaarbaar was dat hy enige sprake van onsterflikheid as futiel sou beskou het. Wat egter ook geblyk het en wat die saak gekompliseerd maak, is dat daar beslis aanduidings is dat hy oor die opstanding, en wat daarmee saamhang, 'n denkproses deurgemaak het en hom daaroor só verskillend uitgelaat het dat dit nie duidelik is hoe hy hom dit alles presies voorgestel het nie.

Ten slotte het dit geblyk dat Crossan se oortuiging van inkonsekwentheid by Paulus net ten opsigte van sy argumentasie rakende die opstanding in 1 Korintiërs 15 tot op sekere hoogte regverdigbaar is, maar dat dieselfde nie van Galasiërs 3:28 gesê kan word nie. Dit is so dat in 1 Korintiërs 15 die metafoor van die saadkorrel en die plant ooreenkoms én verskil impliseer, terwyl die vergelyking tussen hemelse en aardse liggame alleen op verskil dui. Nogtans moet 'n mens jou afvra of dit inderdaad op 'n inkonsekwensie neerkom en of die teenspraak nie eerder daaraan toegeskryf moet word 


\section{Dualistiese antropologie by Paulus?}

dat die saak vanuit verskillende hoeke beredeneer word nie. Wat Galasiërs 3:28 betref, het ek probeer aantoon dat daar voldoende aanduidings is dat Paulus benewens die spirituele ook die fisieke gelykheid van vroue gepropageer en bevorder het en dat daar geen rede is om te vermoed dat hy dit nie, waar moontlik, ook ten opsigte van die slawe sou wou sien gebeur nie. Dat dit in die geval van die slawe klaarblyklik nie moontlik was nie, kan nie aan inkonsekwentheid by Paulus toegeskryf word nie.

\section{Literatuurverwysings}

Aune, D E 1995. Human nature and ethics in Hellenistic philosophical traditions and Paul: Some issues and problems, in Engberg-Pedersen, T (ed). Paul in his Hellenistic context, 291-312. Minneapolis: Fortress.

Barnett, P 1997. The second epistle to the Corinthians. Grand Rapids: Eerdmans. (NIC.)

Best, E 1987. Second Corinthians. Atlanta: John Knox Press. (Interp.)

Bottomley, F 1979. Attitudes to the body in Western Christendom. London: Lepus Books.

Boyarin, D 1994. A radical Jew: Paul and the politics of identity. Berkeley: University of California Press.

Bultmann, R 1967 [1947]. Exegetische Probleme des zweiten Korintherbriefes, in Exegetica: Aufsätze zur Erforschung des Neuen Testaments, 298-322. Tübingen: Mohr.

- 1968. Theologie des Neuen Testaments. 6.Aufl. Tübingen: Mohr.

- 1976. Der zweite Brief an die Korinther. Göttingen: Vandenhoeck. (KEK.)

Conzelmann, H 1968. Grundriss der Theologie des Neuen Testaments. München: Kaiser.

- 1969. Der erste Brief an die Korinther. Göttingen: Vandenhoeck. (KEK.)

Crossan, J D 1998. The birth of Christianity: Discovering what happened in the years immediately after the execution of Jesus. San Francisco: Harper.

Danker, F W 1989. II Corinthians. Minneapolis: Augsburg Publishing House. (ACNT.)

Davies, W D 1990. Paul and the Dead See Scrolls: Flesh and spirit, in Stendahl, K (ed), The scrolls and the New Testament, 157-181, 276-282. New York: Harper.

Dunn, J D G 1998. The theology of Paul the apostle. Grand Rapids: Eerdmans. 
Gundry, R H 1976. Sōma in biblical theology: With emphasis on Pauline anthropology. Cambridge: Cambridge University Press.

Heckel, T K 1993. Der Innere Mensch: Die paulinische Verarbeitung eines platonischen Motivs. Tübingen: Mohr. (WUNT 53.)

Hoffmann, P 1969. Die Toten in Christus: Eine religionsgeschichtliche und exegetische Untersuchung zur paulinischen Eschatologie. 2.Aufl. Münster: Aschendorff. (NTA NF 2.)

Jeremias, J [1958] 1966a. Chiasmus in den Paulusbriefen, in Abba: Studien zur neutestamentlichen Theologie und Zeitgeschichte, 276-297. Göttingen: Vandenhoeck.

- [1955/56] 1966b. Flesh and blood cannot inherit the kingdom of God (1 Cor XV.50), in Abba: Studien zur neutestamentlichen Theologie und Zeitgeschichte, 298-307. Göttingen: Vandenhoeck.

Jewett, R 1971. Paul's anthropological terms: A study of their use in conflict settings. Leiden: Brill. (Arbeiten zur Geschichte des antiken Judentums und des Urchristentums, Band X.)

Joy, N G 1988. Is the body really to be destroyed? (1 Corinthians 5.5). The Bible Translator 39, 429-436.

Käsemann, E 1974. An die Römer. 2. durchgesehene Aufl. Tübingen: Mohr. (HNT 8a.)

Keck, L E 1979. Paul and his letters. Philadelphia: Fortress. (Proclamation Commentaries.)

Kremer, J 1990. 2. Korintherbrief. Stuttgart: Verlag Katholisches Bibelwerk. (Stuttgarter Kleiner Kommentar, Neues Testament 8.)

Lietzmann, H, 1969. An die Korinther 1/II. Ergänzt von Kümmel, W G. 5.Aufl. Tübingen: Mohr. (HNT 9.)

Markschies, C 1994. Die platonische Metapher vom "inneren Menschen": Eine Brücke zwischen antiker Philosophie und altchristlicher Theologie. ZKG 105, 1-17.

Martin, R P 1986. 2 Corinthians. Waco: Word Books Publishers. (Word Biblical Commentary 40.)

Murphy-O'Connor, O P 1991. The theology of the Second Letter to the Corinthians. Cambridge: Cambridge University Press. (New Testament Theology.) 
Meeks, W A 1983. The first urban Christians: The social world of the apostle Paul. New Haven: Yale University Press.

Pelser, G M M 1976. Women and ecclesiastical ministries in Paul. Neotestamentica 10, 92-109.

- 1986. Resurrection and eschatology in Paul's letters. Neotestamentica 20, 36-46.

- 1988. 2 Korintiërs: Die integriteitsprobleem, in Coetzee, J C (red), Koninkryk, Gees en Woord: Huldigingsbundel aangebied aan prof dr Lambertus Floor, 231-249. Pretoria: NG Kerkboekhandel.

- 1991. Die tweede Korintiërbrief as getuienis van apostel en evangelie in krisis en versoening, in Roberts, $\mathrm{J} \mathrm{H}$ et al (reds), Teologie in konteks: Opgedra aan prof A $B d u$ Toit, 219-247. Halfway House: Orion.

Plato. Respublica, in Page, T E et al (eds) 1946. Plato: The Republic, Vol II. London: William Heinemann. (LCL.)

Quast, K 1994. Reading the Corinthian correspondence: An introduction. New York: Paulist Press.

Russell, D S 1964. The message and method of Jewish apocalyptic. Philadelphia: Westminster. (OTLi.)

Sanders, E P 1991. Paul. Oxford: Oxford University Press. (Past Masters.)

Schmithals, W 1969. Die Gnosis in Korinth. 3. Aufl. Göttingen: Vandenhoeck. (FRLANT 66.)

Schnelle, U 1991. Neutestamentliche Anthropologie: Jesus-Paulus-Johannes. Neukirchen: Neukirchener Verlag.

Schrage, W 1982. Ethik des Neuen Testaments. Göttingen: Vandenhoeck. (GNT 4.)

Sellin, G 1986. Die Streit um die Auferstehung der Toten: Eine religionsgeschichtliche und exegetische Untersuchung von 1 Korinther 15. Göttingen: Vandenhoeck. (FRLANT 138.)

Sider, R J 1975. The Pauline conception of the resurrection body in 1 Corinthians XV.35-54. NTS 21, 428-439.

Strobel, A 1989. Der erste Brief an die Korinther. Zürich: Theologischer Verlag (ZBK.NT 6.1.) 
Talbert, C H 1989. Reading Corinthians: A literary and theological commentary on I and 2 Corinthians. New York: Crossroad.

Walter, N 1996. Hellenistische Eschatologie bei Paulus?: Zu 2 Kor 5, 1-10. ThQ 176, 251-269.

Weiss, J 1970. Der erste Korintherbrief. Göttingen: Vandenhoeck. (KEK.)

Wilckens, U 1980. Der Brief an die Römer: 2. Teilband, Röm 6-11. Zürich: Benziger Verlag. (EKK VI/2.)

Windisch, H [1924] 1970. Der zweite Korintherbrief. Göttingen: Vandenhoeck. (KEK.)

Wolff, C 1989. Der zweite Brief des Paulus an die Korinther. Berlin: Evangelische Verlagsanstalt. (ThHK 8.)

- 1996. Der erste Brief des Paulus an die Korinther. Berlin: Evangelische Verlagsanstalt. (ThHK 7.) 